\title{
EPICAUTA DUGESI A VALID SPECIES
}

(COLEOPTERA : MELOIDAE)

\author{
BY F. G. WERNER
}

University of Arizona, Tucson

Some small samples of Epicauta from the states of Nayarit and Sinaloa in Mexico apparently represent the species described by Dugès from San Potosí as E. vittata and designated as $E$. dugesi by Beauregard. A single specimen, probably a female, remains from the Dugès series in the collection of the Instituto de Biología in Mexico City. Champion did not see any specimens from Mexico but decided that Dugès had lemniscata (Fab.) from his description. Dugesi has remained in synonymy with that species ever since.

The male of dugesi differs in several features from the species most closely related to it, vittata (Fab.), lemniscata (Fab.), occidentalis Werner and vitticollis (Haag). All of these have the pad of protarsal segment I of the male slightly heavier than in the female, covering the ventral surface of the segment and extending onto the ventral third to half of the posterior surface. In the male of dugesi the pad is highly developed, covering the ventral surface and extending over all of the posterior surface except for a very small area dorsally at the base, and is much different from the simple pad of the female. The succeeding protarsal segments reflect the condition of the first in all these species. Protarsal segment I is thicker, slightly broader and proportionately shorter in dugesi than it is in the other species; it differs radically from the first segment in occidentalis because that species has all the segments of the protarsi much more slender than they are in the others. A further difference is that the inner (anterior) protibial spur of the male of dugesi is definitely curved, while it is straight or nearly so in the others. Both sexes of dugesi have the head more deeply punctured than the other species, with less of an indication of a median smooth area on the front. The mark- 
ings are little different from those of typical lemniscata; the outer two dark stripes on the elytra are perhaps a bit closer and more diffuse than would be normal for that species. The antennae are essentially as in lemniscata. These comparisons are based on 4 o $\hat{\delta}, 1$ \&, Tepic, Nayarit, July 20, 1955; 1 q, Mazatlán, Sinaloa, July 21, 1955, and 2 of $\delta, 2$ ㅇ $\&$, Los Mochis, Sinaloa, July 22,1955 , all collected at light by R. B. \& J. M. Selander. The following synonymy for dugesi now applies:

\section{Epicauta dugesi Beauregard}

Epicauta vittata Dugès, 1886, Bull. Soc. Zool. France 11: 582 (nomen nudum) ; 1889, An. Mus. Michoacano 2: 87. Not Epicauta vittata (Fab.), 1775.

Epicauta dugesi Beauregard, 1889, Bull. Soc. Ent. France 14: ccxiii. (Substitute name for vittata Dugès nec Fabricius).

Epicauta lemniscata, Champion, 1892, Biol. Cent.-Am., Coleop. 4 (2) : 415, as applied to Mexican specimens. Not Epicauta lemniscata (Fab.), 1801.

Another male specimen collected at light by the Selanders, at Tehuantepec, Oaxaca, June 24, 1955, is quite similar to dugesi in form of protibial spurs and sculpture of head but has protarsal segment I dorso-ventrally flattened and broadened, with a broad pad on this segment confined to the ventral surface. It probably represents still another in this complex of species. 

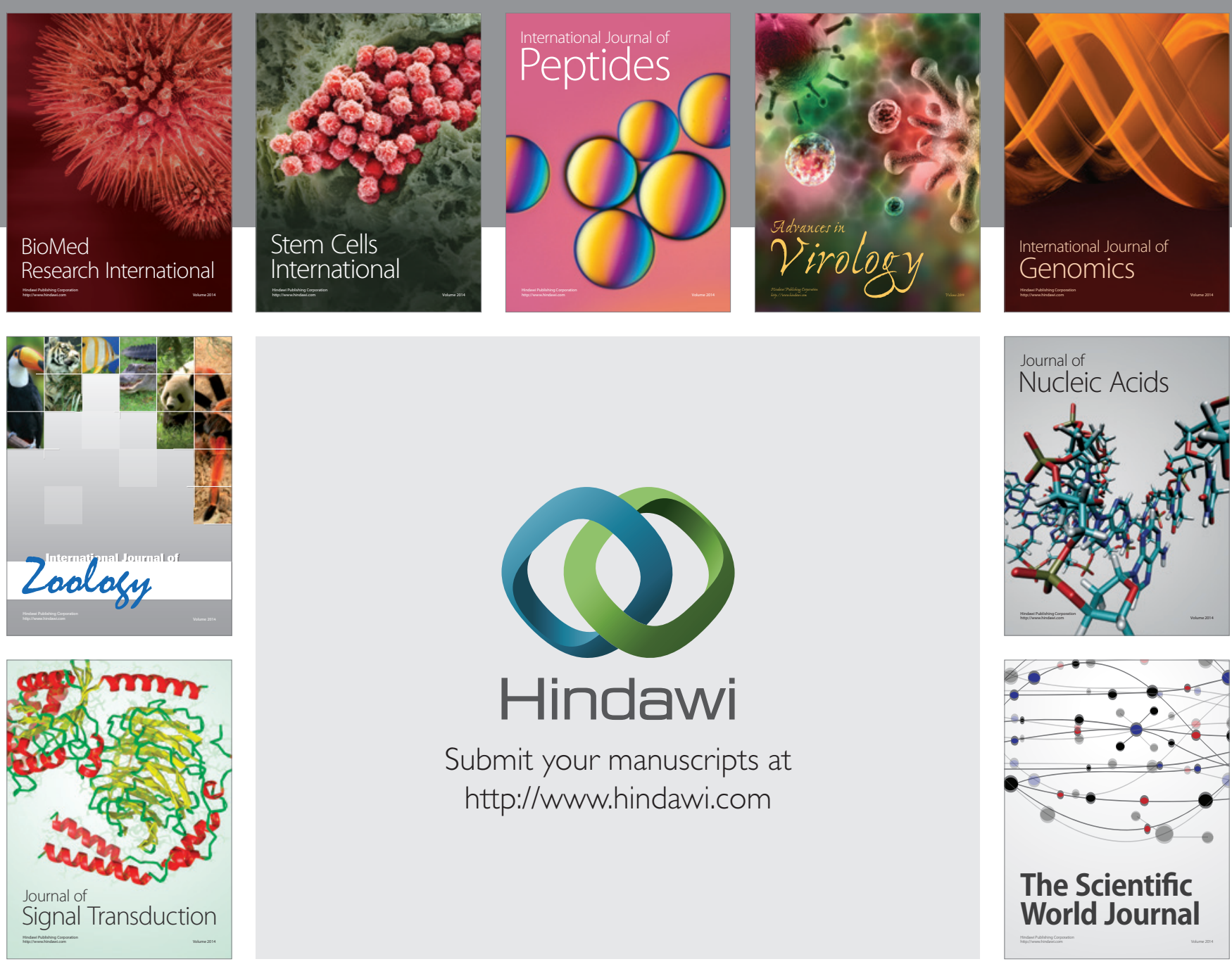

Submit your manuscripts at

http://www.hindawi.com
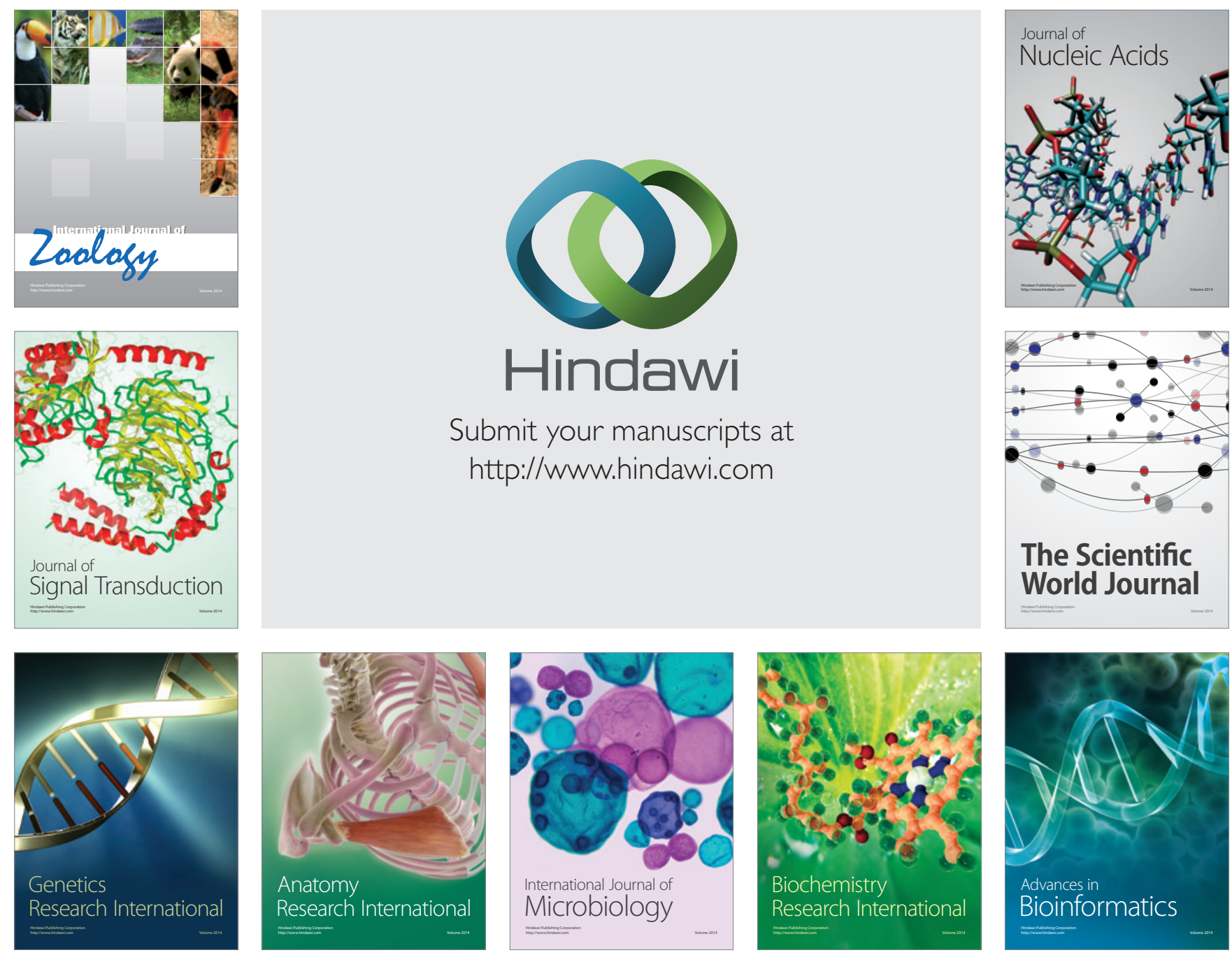

The Scientific World Journal
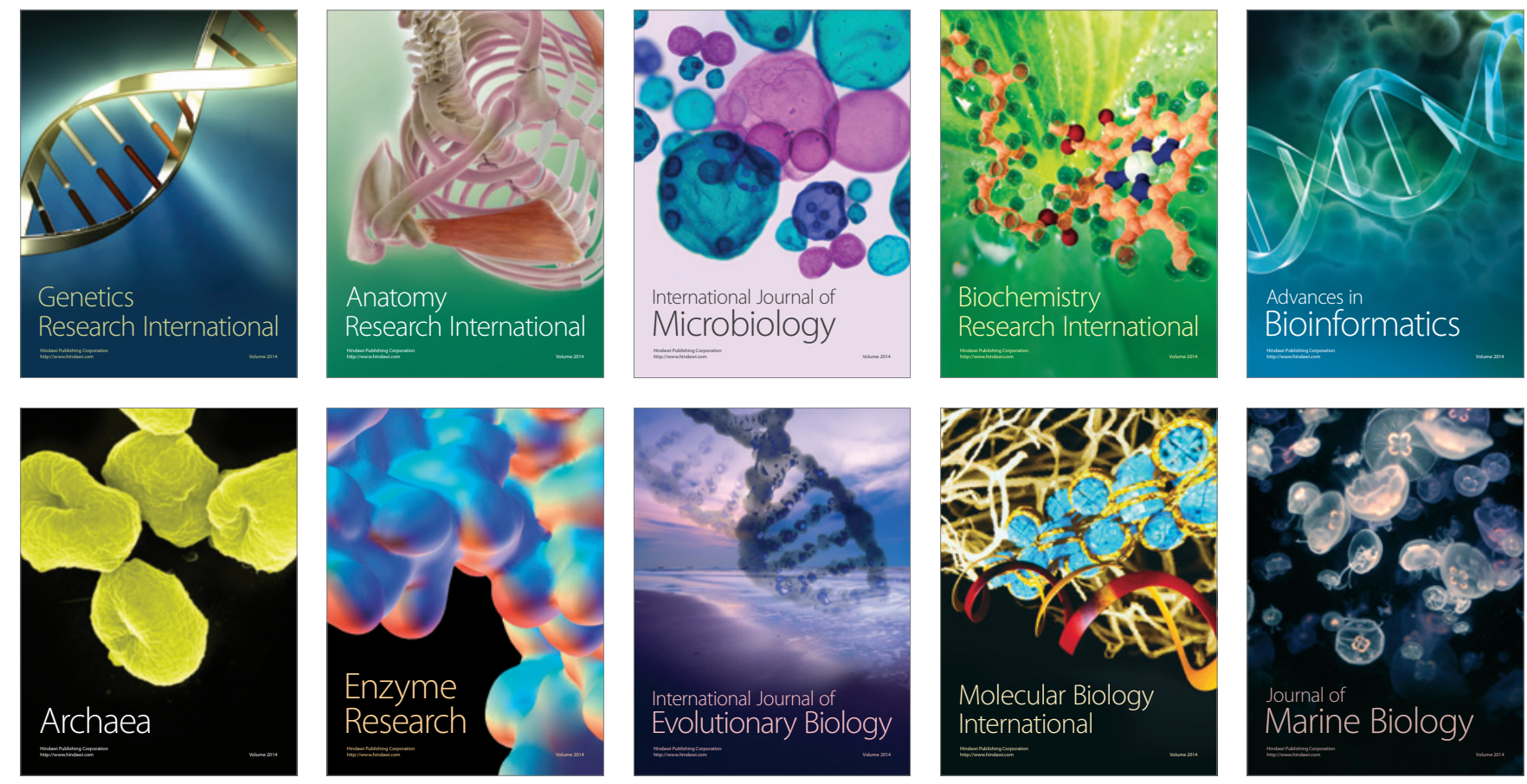